years, compared with 452 applications aggregating more than 500,000 dollars, and the Academy was seeking to increase the number and scope of its awards for recognizing excellence; as yet it had no such award in the social sciences corresponding with its Rumford Medals in the physical sciences, the Amory Prizes in the medical sciences and the Emerson-Thereau Medal in the broad field of literature. The Academy had made no public pronouncement during the period, but Mr. Mather was not satisfied that there had been a suitable theme, and he inclined to think that the Academy was doing what it should more effectively by providing the information to illumine the problems on which policy makers must make their decisions.

As regards the future, Mr. Mather said that the Carnegie Corporation had made a grant of 50,000 dollars for each of the next two years for the continua. tion of the Academy's conference and study programme. It would be necessary in the next four years to assess the value of the Academy's house and the function of the Academy in the State, but he thought that the Academy's outstanding opportunity and responsibility in the next decade lay in serving as a liaison between the community of practical affairs and the practitioners and scholars in the arts and sciences.

\title{
BRITISH COLUMBIA RESEARCH COUNCIL
}

\begin{abstract}
MONG the varied research items described in the seventeenth annual report of the British Columbia Research Council is one into marine borer control (Pp. 16. Vancouver: British Columbia Research Council, 1961). During 1960-61 the stations recording marine-borer breeding were increased to more than thirty as more companies engaged the Division of Applied Biology for protecting logs and wooden installations against losses by borers. By its larval inspection and log-scheduling service, the Division undertook the protection of more than 100 million feet of timber in sea-water storage for Canadian companies and a similar volume for a company in Puget Sound, where the intensity of marine-borer attack is the highest on the North Pacific Coast.

In instances where serious damage by borers would occur before the logs could be used, the rafts were treated chemically by a sprinkling system developed by the Council. During 1960-61 more than 100 sections of high-grade stock were treated in this way prior to hauling from Alaska to Puget Sound; a total of 10 million board feet of wood were chemically treated.
\end{abstract}

One of the outstanding achievements in this field in 1960 was the development of a sonic device for testing the internal condition of pilings. This unit accurately reveals even minor damage by borers in piling. The unit has been used for testing the soundness of piling in wharves on Vancouver Island and in Vancouver Harbour. Operating in conjunction with a diver, 130 piles a day can be examined.

Also developed during the past year was a technique for enshrouding individual piles so that they can be treated chemically to kill embedded borers. This method was developed to protect uncreosoted piles which are used in many logging operations on the coast and as fender piles on many wharfs. The shroud is all plastic to avoid corrosion in sea-water, and can readily be clipped on and off a pile without the use of hooks.

A number of field studies on Bankia setacea, the local teredo-like borer, is being made. These include the susceptibility of different species of wood to attack, the rate of loss by different species, the effect of water temperature on breeding, and studies on the borer itself.

The Canadian Uranium Research Foundation has recently made a grant of 10,000 dollars a year for investigation into the use of uranium compounds as toxicant additives to wood impregnants for marine borers.

\section{RECRYSTALLIZATION OF LEAD AND ZINC SULPHIDES}

\author{
By DR. J. C. NIXON \\ Consolidated Zinc Pty. Ltd., North Melbourne, Victoria \\ AND \\ J. D. HAYTON, D. C. LAWRIE and A. E. TYNAN \\ Australian Mineral Development Laboratories, Parkside, South Australia
}

\begin{abstract}
DEAS advanced in recent years for the formation of conformable ore deposits of base metals (the Broken Hill lead-zine deposit in New South Wales is one of these) imply that the observed ore textures were developed by crystallization or re-crystalliza. tion after initial deposition. The earlier ideas depended in part on the assumption that the mineral textures were original and depositional. Since a useful understanding of the history of these deposits could be of assistance in exploration, some simple experiments were conducted to find out whether the
\end{abstract}

textural condition of lead and zinc sulphides was or was not affected by temperatures which might be attained in deep burial and in high-rank metamorphism.

Chemically precipitated sulphides of lead and zinc were subjected to prolonged treatment in sealed vessels at elevated temperatures. The sulphides were prepared by precipitation with hydrogen sulphide from solutions of lead and zinc salts. The washed precipitates were dried at $90^{\circ} \mathrm{C}$. in an inert atmosphere, and stored in a vacuum desiccator. Samples of each 